\title{
Chlorpyrifos Residue in Washed and Unwashed Tomatoes
}

\author{
Hasnawati Amqam ${ }^{1}$, Ruslan La Ane ${ }^{2}$, Syamsuar Manynyulei ${ }^{3}$, Stang $^{4}$, M.Rum Rahim ${ }^{5}$, Putri \\ Resky Novianti ${ }^{6}$, Anwar Mallongi $^{7}$ \\ \{hasnawati.amqam@unhas.ac.id ${ }^{1}$, ruslan.ane@unhas.ac.id ${ }^{2}$, manongkoki@yahoo.com ${ }^{3}$, \\ stangbios@gmail.com ${ }^{4}$, muhammadrumrahim@gmail.com ${ }^{5}$, putriresky04@gmail.com ${ }^{6}$, \\ anwar_envi@yahoo.com ${ }^{7}$ \} \\ Department of Environmental Health, Faculty of Public Health, Universitas Hasanuddin ${ }^{1,2,3,6,7}$ \\ Department of Biostatistics, Faculty of Public Health, Universitas Hasanuddin ${ }^{4}$ \\ Department of Occupational Health and Safety, Faculty of Public Health, Universitas Hsanuddin ${ }^{5}$
}

\begin{abstract}
The use of chlorpyrifos insecticide by farmers is one of the ways to increase crop productivity. However, its residues in agricultural products will result in many health problems, both acute and chronic. The residue may be reduced through some treatment. This study aimed to analyze the chlorpyrifos residues in tomatoes with and without washing. Quasi-experiment was applied in this study. Tomatoes samples were obtained from the Village of Jennetallasa, Rumbia, Jeneponto Regency. Chlorpyrifos analysis using gas chromatography method. The results showed that the residue levels of the chlorpyrifos with washing using piped water, mountains water, and without washing are $0.006 \mathrm{mg} / \mathrm{kg}, 0.016 \mathrm{mg} / \mathrm{kg}, 0.050 \mathrm{mg} / \mathrm{kg}$ respectively. The conclusions of this study are the levels of residues in washed tomatoes were lower than unwashed.
\end{abstract}

Keywords: Cholinesterase inhibitors, insecticides, fruit

\section{Introduction}

Chlorpyrifos insecticide residues in agricultural products can cause health problems (poisoning), both acute and chronic. Chlorpyrifos insecticide residues in humans can result in numbness, tingling sensation, coordination problems, headaches, dizziness, tremors, nausea, abdominal cramps, sweating, lacrimation, saliva, blurred vision, breathing difficulties or respiratory depression, slow heartbeat, muscle fasciculation, and in some cases can cause polyneuropathy. [1], [2] Chlorpyrifos is available in the emulsion, dust, spray, granular, and moistened powder formulations. It is used as an insecticide on grasses, ornamental plants, seeds, cotton, fields, fruits, nuts, and vegetables.

Vegetables are one of the horticultural commodities that humans need because staple foods can not substitute the content of vitamins, carbohydrates, and minerals, so their existence is very important to fulfill human nutrition. These vegetables are very susceptible to plant pests and diseases; pesticide residues in vegetables indicate that pesticide use is quite intensive at the farmer level. According to Yenita's research in the Kartama estate in Marpoyan Damai Pekanbaru, there are organophosphate insecticides in green spinach vegetables which are $0.0520 \mathrm{mg} / \mathrm{kg}$.[3] 
Food processing is an effort to reduce levels of insecticide residues. One of the food processing processes is the washing process. The washing process in food ingredients is a common thing to do at home because it can be done using water or washing solutions available in the kitchen.[4] There is a washing and boiling effect on the levels of chlorpyrifos residues in long beans. [5] The washing process in vegetables is often done by the community. In general, washing is done by using PDAM water while in Jenetallasa Village people use mountain water.

Based on data from BPS on Jeneponto Regency Food Crops in 2015, tomato production in Jeneponto was 2,624 tons. Vegetable tomato production in Jeneponto Regency has increased every year [6]. One of the tomato producing areas in Jeneponto Regency is Jenetallasa Village, Rumbia District. Most farmers in this village use insecticides to increase food production with the aim that pests and diseases do not damage the plants. Tomato farmers in this village mostly use Dursban, an insecticide brand that contains chlorpyrifos.

The use of pesticides in vegetable crops in the highlands is very intensive; this is mainly due to cold climatic conditions with humidity and high rainfall, creating good conditions for the proliferation of pests and plant diseases. Based on the facts presented earlier, the authors intend to analyze chlorpyrifos pesticide residues in tomatoes in Jenetallasa Village, Rumbia District, Jeneponto Regency.

\section{Methods}

The type of research used was quasi-experiment, which analyzed the levels of chlorpyrifos residues in tomatoes with and without washing. Tomatoes were taken directly in one of the tomato plants in Jenetallasa Village, Rumbia District, Jeneponto Regency. Tomatoes that became the sample were tomatoes sprayed with chlorpyrifos in Jenetallasa Village, Rumbia District, Jeneponto Regency. Examination of the sample is done by using the gas chromatography method.

Samples that are not treated, directly taken from Total Wrap Aluminum Foil then extracted. Meanwhile, samples of tomatoes that were treated were washed using running piped water- distributed by Local Water Supply Companies- and spring water, taken from a water spring in Jenetallasa village using bottles.

\subsection{Extraction}

Tomatoes were crushed first using a chopper and blender. The tomato sample weighed \pm 15 grams, then put it in a $50 \mathrm{ml}$ centrifuge tube, then added $10 \mathrm{ml}$ of acetonitrile and the tube was closed. After vigorously shaken for 45 seconds, 6 grams of $\mathrm{MgSO} 4$ and 1.5 grams of $\mathrm{CH} 3 \mathrm{COONa}$ were added and shaken again for 45 seconds. After centrifuged for 2 minutes at a speed of $4000 \mathrm{rpm}$, the supernatant was taken and put into a centrifuge tube. Added $50 \mathrm{mg}$ PSA and $150 \mathrm{mg} \mathrm{MgSO}$, the tube was closed and shaken for 20 seconds then centrifuged for 2 minutes at a speed of $400 \mathrm{rpm}$. A total of $0.5 \mathrm{ml}$ of the supernatant was transferred to the vial for gas chromatography and then injected into gas chromatography. Chlorpyrifos is dissolved in $5 \mathrm{ml}$ of iso-oktan: toluene (90:10. V/v).

\subsection{Determination, Calculation, and Detection Limit}


The extracted sample was injected 1-2 $\mathrm{ml}$ of extract into gas chromatography. Then the results can be seen using graphs. The results of the resistance time and height or peak area of the chromatogram obtained from tomato solution were compared with the standard comparison solution. The limit of detection of determination of gas chromatography equipment is $0.001 \mathrm{mg} / \mathrm{kg}$.

\section{Result}

Based on interviews with one of the tomato farmers in Jenetallasa village, data on the types of pesticides and the active ingredients used were cypermethrin (Arrivo and Cipermax), chlorpyrifos (Dursban), profenofos (Curacron), and methomyl (Lannate) (Table 1). According to them, the dose of pesticide used is by the rules of use contained in the pesticide label. However, sometimes using doses that exceed the rules of use that exist if pest attacks increase. The time of spraying is usually done during the day with the frequency of spraying from flowering tomato plants to harvest time of 16-20 times, and sometimes the pesticides are mixed with other pesticides. Pesticides used to depend on the pests that attack the plants.

Table 1. Brand and Active Ingredients used by Tomatoes Farmers in Rumbia Village Jeneponto District

\begin{tabular}{lc}
\hline \multicolumn{1}{c}{ Brands } & Active Ingredients \\
\hline Dursban 200 EC & Chlorpyrifos \\
Arrivo 30 EC & Cypermethrin \\
Lannate 25 WP & Metomil \\
Curacron 500 EC & Profenofos \\
Cipermax 100 EC & Cypermethrin \\
\hline
\end{tabular}

Before washing the tomato sample, the researchers examined the chlorine level in the washing water, which is piped water and mountain water using the Test Kit. The results of the examination of chlorine levels in washing water show $0 \mathrm{mg} / 1$ (undetectable). The results of chlorpyrifos pesticide residue examination on fruit tomatoes by gas chromatography method revealed that chlorpyrifos residues in washed tomatoes using piped water was the lowest $(0,006 \mathrm{mg} / \mathrm{kg})$ compared to washing with mountain water $(0,016 \mathrm{mg} / \mathrm{kg})$ and unwashed tomatoes (Tabel 2).

Table 2. Chlorpyrifos residue in tomatoes

\begin{tabular}{lc}
\hline \multicolumn{1}{c}{ Tomatoes } & Residue Level (mg/kg) \\
\hline Piped-water washed tomatoes & 0,006 \\
Mountain water washed tomatoes & 0,016 \\
Unwashed tomatoes & 0,050 \\
\hline
\end{tabular}

\section{Discussion}

Testing of chlorpyrifos pesticide residues in fruit tomatoes from Jenetallasa Village, Rumbia Subdistrict, Jeneponto Regency with and without pecuniary showed differences in chlorpyrifos residues in these vegetables. The existence of this difference cannot be separated from the washing treatment given. Chlorpyrifos pesticide residue levels in tomatoes by washing use lower flowing PDAM water than washing using mountain water or tomatoes 
without washing. The difference in the reduction of residual levels between tomatoes washed using PDAM water with tomatoes using mountain water is likely due to the swift flow of PDAM water from the tap. Water from the mountains is channeled from mountain water reservoir bottles. The strength of the flow will erode pesticide residues attached to fruits and vegetables [7].

Testing of chlorpyrifos pesticide residues in fruit tomatoes from Jenetallasa Village, Rumbia Subdistrict, Jeneponto Regency with and unwashed showed differences in chlorpyrifos residues in these vegetables. The existence of this difference cannot be separated from the washing treatment given. Chlorpyrifos pesticide residue levels in tomatoes by washing use lower flowing PDAM water than washing using mountain water or tomatoes without washing. The difference in the reduction of residual levels between tomatoes washed using PDAM water with tomatoes using mountain water is likely due to the swift flow of PDAM water from the tap. Water from the mountains is channeled from mountain water reservoir bottles. The strength of the flow will erode pesticide residues attached to fruits and vegetables [8].

Chlorpyrifos-methyl pesticide residue levels in tomatoes by washing $(0.006 \mathrm{mg} / \mathrm{kg}$ for PDAM water and $0.016 \mathrm{mg} / \mathrm{kg})$ and without washing $(0.05 \mathrm{mg} / \mathrm{kg})$ are still below the Maximum Residue Limit (BMR) stipulated by the Minister of Agriculture Regulation Republic of Indonesia number 04 / Permentan / PP.340 / 2/2015 which is $1 \mathrm{mg} / \mathrm{kg}$ and Rfd (Reference Dose) as determined by WHO, which is $0.1 \mathrm{mg} / \mathrm{kgBB}$. Unlike the maximum number of ADI (Acceptable Daily Intake), which is $0-0.01 \mathrm{mg} / \mathrm{kgBB}$, where tomatoes are not washed and with washing using mountain water exceeds the maximum number. It also approaches the NOEL (No-Effect Level) value for inhibition of BuChE, one of the cholinesterase enzymes, which is $0.005 \mathrm{mg} / \mathrm{kgBB}$ [9]

The results of research conducted by Maruli, et al. in the Dolat Rakyat Village, Karo Regency showed that chlorpyrifos residues in freshly harvested cabbage were $0.698 \mathrm{mg} / \mathrm{kg}$, the cabbage washed using flowing water from PAM was $0.165 \mathrm{mg} / \mathrm{kg}$, cabbage soaked with PAM water was $0.526 \mathrm{mg} / \mathrm{kg}$, muted cabbage using vinegar was $0.450 \mathrm{mg} / \mathrm{kg}$, cabbage soaked using salt water was $0.238 \mathrm{mg} / \mathrm{kg}$, cabbage soaked in lime juice of $0.370 \mathrm{mg} / \mathrm{kg}$, cabbage washed using PAM running water and boiled at $0.161 \mathrm{mg} / \mathrm{kg}$. [4]

Insecticide residual analysis is carried out based on pesticide residue testing methods issued by the Department of Agriculture's Pesticide Commission by referring to the method recommended by the Codex Alimentarius Commission (CAC) with the use of GC-MS Gas Chromatography. Stages of analysis include: Extraction, mixing (homogeneous) using centrifuges, making standard solutions, and determining or calculating residual levels [10]

Parameters or approaches used in this study are retention time (tR) in the same or stable tool condition. Qualitatively the compound will be detected at peak and retention time. For quantitative analysis can be done by calculating the parameters of peak height and peak area and calculating pesticide residue levels at the peak, which shows the same retention time with the standard [11]. The laboratory results of the Food Crops and Horticulture Protection Agency Maros showed that the measurement of retention time for chlorpyrifos in the sample tomatoes with and without washing is the same as retention times at standard chromatograms, so it can be said that tomato samples with and without washing contain chlorpyrifos pesticide residues. The results of the Nazmatullaila study in Jakarta, the levels of deltamethrin pesticide residues for unwashed tomatoes amounted to $1.443 \mathrm{mg}$. $\mathrm{Kg}$, washing with running water of $0.672 \mathrm{mg} / \mathrm{kg}$, soaking with $0.9 \% \mathrm{NaCl}$ of $0.611 \mathrm{mg} / \mathrm{kg}$, soaking with $5 \% \mathrm{NaCl}$ of $0.449 \mathrm{mg}$ $/ \mathrm{kg}$, soaking with $10 \% \mathrm{NaCl}$ of $0.41 \mathrm{mg} / \mathrm{kg}$. The results of profenofos pesticide residue levels for unwashed tomatoes were $2.162 \mathrm{mg} / \mathrm{kg}$, washing with flowing water of 1,439 mg / 
$\mathrm{kg}$, soaking with $0.9 \% \mathrm{NaCl}$ of $1,943 \mathrm{mg} / \mathrm{kg}$, soaking with $5 \% \mathrm{NaCl}$ of $1,084 \mathrm{mg} / \mathrm{kg}$, soaking with $10 \% \mathrm{NaCl}$ is $1,731 \mathrm{mg} / \mathrm{kg}$. [12].

Triani's research results in Tabanan Regency, the level of diazinon insecticide residues in long beans after washing with running water for 30 seconds, obtained an initial residual level of $0.0222 \mathrm{mg} / \mathrm{kg}$ after treatment to $0.0015 \mathrm{mg} / \mathrm{kg}$, while the residual content in nuts the length is washed for 15 seconds, then boiled for 15 minutes the resulting residue is 0.0009 $\mathrm{mg} / \mathrm{kg}$. There is a decrease in residual levels after washing and boiling [13].

The results of Atmawidjaja's research, et al. in Bandung, levels of pesticide residues meditation on tomatoes without spraying were detected, tomatoes sprayed with pesticides 2 days before harvest (tomato A) of $0.86 \mathrm{mg} / \mathrm{kg}$, tomatoes 6 days after spraying by $0.11 \mathrm{mg} / \mathrm{kg}$, tomatoes A washed with distilled water by $0.08 \mathrm{mg} / \mathrm{kg}$, tomatoes A washed with detergent water by $0.07 \mathrm{mg} / \mathrm{kg}$, tomatoes A which are sliced and then boiled undetectable, tomatoes A without slicing then boiled at $0.15 \mathrm{mg} / \mathrm{kg}$. [14]

\section{Conclusion}

Tomatoes with and without washing in Jenetallasa Village, Rumbia District, Jeneponto Regency contain chlorpyrifos residues. Washing using PDAM water has lower levels of chlorpyrifos residues than tomatoes by washing with mountain water or without washing. Suggestions from this study are the government and related institutions such as the Health Office to conduct counseling on how to effectively handle pesticide residues. To the community to wash vegetables or fruit by using the heavy flow of water

\section{Reference}

1. Testai E, Burarti FM, Consiglio ED.: Chlorpyrifos, Handbook of Pesticide Toxicology, Edition 2. USA: Elsevier.pp.34-40 (2011)

2. Eaton DL.: Review of the Toxicology of Chlorpyrifos with an Emphasis on Human Exposure and Neurodevelopment. Critical Reviews in Toxicology.Vol.38.pp.1-125(2008).

3. Yenita, RN., Amin B., Jose C.:Analisis Kadar Residu Pestisida Organofosfat dan Antioksidan pada Bayam (Amaranthus sp) diPerkebunan Kartama Kecamatan Marpoyan Damai Pekanbaru. Jurnal Ilmu Lingkungan.Vol.6.pp.3-9.(2012)

4. Maruli A., Santi DN., Naria E.:Analisa Kadar Residu Insektisida Golongan Organofosfat pada Kubis (Brassica oleracea) setelah Pencucian dan Pemasakan di Desa Dolat Rakyat Kabupaten Karo Tahun 2012. Jurnal Lingkungan dan Kesehatan Kerja.Vol.1.pp.2-9.(2013)

5. Dinanti, DRP., Triani IGAL., Satriawan IK.: Pengaruh Perlakuan Pencucian dan Perebusan terhadap Kadar Residu Insektisida Klorpirifos dan Karakteristik Kacang Panjang (Vigna sinesis). Jurnal Pertanian. Vol.3.pp.47-57 (2014)

6. Badan Pusat Statistik. Statistik Pertanian Tanaman Pangan dan Hortikultura Kabupaten Jeneponto Tahun 2015. Jeneponto: Badan Pusat Statistik (2015)

7. Pujiono. Kiat Menghilangkan Residu Pestisida pada Sayuran dan Buah. [Online Article]. Available at https://beritagar.id/artikel/gaya-hidup/kiat-membersihkan-sayuran-dan-buah-dari-residu-pestisida. (2016)

8. Kristianingrum S.: Kajian Berbagai Metode Analisis Residu Pestisida dalam Bahan Pangan. Jurnal Jurusan Pendidikan Kimia FMIPA UNY.pp.34-40 (2009)

9. Kementerian Pertanian RI.: Pengawasan Keamanan Pangan terhadap Pemasukan dan Pengeluaran Pangan Segar Asal Tumbuhan. Jakarta: Kementerian Pertanian RI.pp.1-8 (2015) 
10. Yumarto, Gassa A., Sjam S.: Uji Residu Insektisida pada Buah Cabai (Capsium annum Linnaeus) di Kabupaten Pinrang Provinsi Sulawesi Selatan. jurnal Hama dan Penyakit Tumbuhan.Vol.1.pp.2-9 (2012)

11. Marzuki A.: Analisis Residu Klorpirifos Pada Sawi Hijau (Brassica Rapa Var. Parachinensis L.) terhadap Parameter Waktu Retensi Metode Kromatografi Gas. Jurnal Pharmacon. Vol.3.pp.4.(2014)

12. Nazmatullaila S.: Analisis Residu Pestisida pada Tomat Menggunakan Metode QuEChERS dengan Perlakuan Sebelum dan Setelah Dicuci [Tesis]. Jakarta: UIN Syarif Hidayatullah.pp.45-50.(2015)

13. Triani AL., Gusti I.: Residu Insektisida Sidazinon pada Kacang Panjang (Vigna sinesis) yang Dihasilkan di Desa Tunjuk Selatan, Kecamatan Tabanan, Kabupaten Tabanan. Jurnal Bumi Lestari. Vol.10.1-9 (2007)

14. Atmawidjaja A., Tjahjono DH. Pengaruh Perlakuan terhadap Kadar Residu Pestisida Metidation pada Tomat. Jurnal Acta Pharmaceutica Indonesia. Vol.29.pp.1-9 (2004) 